\title{
PENERAPAN MODELPEMBELAJARANKOOPERATIF TIPE STAD UNTUK MENINGKATKAN KEMAMPUAN MENULIS SISWA KELAS 10 SMK NEGERI 1 TONGKUNO
}

\author{
oleh: \\ USMAN \\ Kepala Sekolah SMK Negeri 1 Tongkuno \\ Email: usmansmk1tongkuno@gmail.com
}

\begin{abstract}
ABSTRAK
Hasil penelitian menunjukkan bahwa (1) penerapan model pembelajaran kooperatif tipe Student Team Achievement Division (STAD) pada mata pelajaran Bahasa Indonesia siswa kelas 10 SMK Negeri 1 Tongkuno dapat meningkatkan kualitas proses maupun hasil belajarsiswa.Siswa aktif mengerjakan tugas tugas melalui LKS dengan baik,keterampilan bertanya siswa meningkat disertai kemampuan menjawab pertanyaan,baik dari guru maupun siswa. Hal ini berarti model pembelajaran kooperatif tipe Student Team Achievement Division (STAD) dapat membentuk mental siswa untuk berani mengemukakan ide/gagasan disertai rasa saling menghargai pendapat siswa lainnya sebagai peserta belajar.(2)Pelaksanaan model pembelajaran kooperatif tipe Student Team Achievement Division (STAD) dalam pembelajaran Bahasa Indonesia dapat meningkatkan hasil belajar Bahasa Indonesia materi menulis puisi bebas pada siswa kelas 10 SMK Negeri 1 Tongkuno. Hasil tes siklus I, yaitu dari 66,7\% yang mencapai ketuntasan belajar, indicator ketuntasan belajar yang ditargetkan pada siklus I belum tercapai namun pada siklus II meningkat menjadi83,33\%.yang memperoleh skor minimal70.Artinya peningkatan prestasi dari siklus I kesiklus II sebesar 16,63\% sehingga ketuntasan belajar Bahasa Indonesia siswa dapat tercapai. Berdasarkan hasil penelitian disarankan guru menerapkan model pembelajaran kooperatif tipe Student Team Achievement Division (STAD)dalam mengajarkan mata pelajaran di sekolah, karena model pembelajaran ini efektif meningkatkan hasil belajar Bahasa Indonesia siswa secara signifikan.
\end{abstract}

\section{Kata Kunci: Pembelajaran Kooperatif Tipe STAD, Kemampuan Menulis}

\section{PENDAHULUAN}

Dalam mencapai tujuan pembelajaran umum pada mata pelajaran Bahasa Indonesia di Sekolah masih banyak mengalami kesulitan. Hal ini terlihat dari masih rendahnya hasil belajar mata pelajaran Bahasa Indonesia dibandingkan dengan hasil belajar beberapa mata pelajaran lainnya. Berdasarkan kenyataan pada tempat mengajar penulis yakni di SMK Negeri 1 Tongkuno khususnya pada kelas 10 terlihat rata-rata hasil belajar Bahasa Indonesia pada kemampuan menulis puisi bebas siswa masih tergolong rendah rata-rata siswa memperoleh nilai di bawah dari standar KKM yang ditentukan oleh sekolah yakni 70. Data hasil belajar siswa kelas 10 pada semester genap tahun ajaran 2015/2016 diketahui bahwa ketuntasan belajarsiswa secara klasikal sebesar 
60,86\%. Penyebab rendahnya hasil belajar Bahasa Indonesia siswa adalah model pembelajaran yang diterapkan oleh guru dalam membelajarkan materi pelajaran di mana guru cenderung menerapkan model pembelajaran yang monoton yakni ceramah. Tentunya hal ini berakibat pada aktivitas pembelajaran siswa di mana siswa cenderung pasif dalam menerima pelajaran dan banyak siswa yang hanya bercanda gurau serta saling mengganggu antar satu sama lain.

Model pembelajaran jenisnya beragam yang masing-masing memiliki kelebihan dan kelemahan, maka pemilihan model yang sesuai dengan topik atau pokok bahasan yang akan diajarkan harus betul-betul dipikirkan oleh guru yang akan menyampaikan materi pelajaran. Penulis mencoba menerapkan salah satu modelpembelajaran yang dapat meningkatkan peran siswa dan guru dalan pembelajaran yakni model pembelajaran kooperatif tipe Student Team Achievement Division (STAD).Model pembelajaran ini menuntut setiap siswa untuk bertanggung jawab tentang ketuntasan materi pembelajaran dan dapat menyampaikan materi tersebut kepada anggota kelompoknya.

Berdasarkan keunggulan model pembelajaran kooperatif tipe STAD dapat diyakinkan bahwa hasil belajar siswa pada materi Kemampuan Menulis Siswa masih dapat ditingkatkan melalui penerapan model pembelajaran kooperatif tipe STAD.

Pembelajaran kooperatif mendorong dan memberi kesempatan kepada siswa untuk terampil berkomunikasi. Artinya, siswa didorong untuk mampu menyatakan pendapat atau idenya dengan jelas, mendengarkan orang lain dan menanggapinya dengan tepat, meminta tanggapan balik (feedback) serta mengajukan pertanyaan-pertanyaan dengan baik. Siswa juga mampu membangun dan menjaga kepercayaan, terbuka untuk menerima dan memberi pendapat serta ide-idenya, mau berbagi informasi dan sumber, mau memberi dukungan pada orang lain dengan tulus.

Tabel 1. Langkah-langkah Pembelajaran Kooperatif Tipe STAD

\begin{tabular}{|c|c|}
\hline Fase & Tingkahlaku Guru \\
\hline $\begin{array}{l}\text { Fase -1 } \\
\text { Menyampaikan tujuan dan } \\
\text { memotivasi siswa }\end{array}$ & $\begin{array}{l}\text { Guru menyampaikan semua tujuan pelajaran yang ingin } \\
\text { dicapai pada pelajaran tersebut dan memotivasi siswa }\end{array}$ \\
\hline $\begin{array}{l}\text { Fase - } \mathbf{2} \\
\text { Menyajikan informasi }\end{array}$ & $\begin{array}{l}\text { Guru menyajikan informasi kepada siswa dengan jalan } \\
\text { demonstrasi atau lewat bacaan }\end{array}$ \\
\hline $\begin{array}{l}\text { Fase - 3 } \\
\text { Mengorganisasikan siswa ke } \\
\text { dalam kelompok - kelompok } \\
\text { belajar }\end{array}$ & $\begin{array}{l}\text { Guru menyampaikan kepada siswa bagaimana cara } \\
\text { membentuk kelompok belajar pada saat mereka } \\
\text { mengerjakan tugas }\end{array}$ \\
\hline $\begin{array}{l}\text { Fase } \mathbf{- 4} \\
\text { Membimbing kelompok bekerja } \\
\text { dan belajar }\end{array}$ & $\begin{array}{l}\text { Guru membimbing kelompok-kelompok belajar pada } \\
\text { saat mereka mengerjakan tugas mereka }\end{array}$ \\
\hline $\begin{array}{l}\text { Fase }-5 \\
\text { Evaluasi }\end{array}$ & $\begin{array}{l}\text { Guru mengevaluasi hasil belajar tentang materi yang } \\
\text { telah dipelajari atau masing-masing kelompok }\end{array}$ \\
\hline
\end{tabular}


mempresentasikan hasil kerjanya

\begin{tabular}{ll}
\hline $\begin{array}{l}\text { Fase }-\mathbf{6} \\
\text { Memberikan penghargaan }\end{array}$ & $\begin{array}{l}\text { Guru mencari cara untuk menghargai upaya maupun } \\
\text { hasil belajar individu atau kelompok }\end{array}$ \\
\hline
\end{tabular}

Trianto (2010: 71)

Setelah diperoleh hasil tes, kemudian dihitung skor peningkatan individual berdasarkan selisih pemerolehan skor tes terdahulu (skor dasar) dengan skor tes terakhir. Berdasarkan skor peningkatan individual dihitung poin perkembangan dengan menggunakan pedoman yang disusun oleh slavin (Asma, 2006: 85) seperti pada tabel 2.3 berikut.

Tabel 2. Penghitungan Skor Perkembangan pada Belajar Kooperatif

\begin{tabular}{lc}
\hline \multicolumn{1}{c}{ Skor Tes Akhir } & $\begin{array}{c}\text { Nilai } \\
\text { peningkatan }\end{array}$ \\
\hline $\begin{array}{l}\text { Lebih dari 10 poin } \\
\text { dibawah skor dasar }\end{array}$ & 5 poin \\
\hline $\begin{array}{l}\text { 10 Poin hingga 1 poin } \\
\text { dibawah skor }\end{array}$ & 10 poin \\
\hline $\begin{array}{l}\text { Skor awal hingga 10 } \\
\text { poin di atas skor dasar }\end{array}$ & 20 poin \\
\hline $\begin{array}{l}\text { Lebih dari 10 poin } \\
\text { diatas skor dasar }\end{array}$ & 30 poin \\
\hline Pekerjaan sempurna & 30 poin \\
\hline
\end{tabular}

\section{METODE PENELITIAN}

\section{Setting Penelitian}

Penelitian ini telah dilaksanakan pada semester genap tahun ajaran 2016/2017 di kelas 10 SMK Negeri 1 Tongkuno. Dengan pertimbangan bahwa kelas 1 memiliki rata-rata nilai hasil belajar yang belum maksimal dan belum sepenuhnya menerapkan model pembelajaran kooperatif tipe STAD.

\section{Subjek Penelitian}

Subjek penelitian tindakan kelas ini terdiri atas 1 orang guru mata pelajaran Bahasa Indonesia sebagai guru kolaborasi dan siswa (i) kelas 10 SMK Negeri 1 Tongkuno Kebupaten Muna yang berjumlah 16 orang dengan rincian 7 orang laki-laki dan 9 orang perempuan.

\section{Faktor yang Diteliti}

Adapun faktor-faktor yang diteliti dalam upaya menjawab permasalahan penelitian ini adalah sebagai yaitu faktor siswa dan faktor guru

\section{Prosedur Penelitian}

Prosedur penelitian ini dilaksanakan dalam dua siklus. Tiap siklus sesuai dengan perubahan yang ingin dicapai pada faktor-faktor yang diselidiki.

Secara rinci prosedur penelitian tindakan kelas tersebut dapat dijabarkan sebagai berikut.

1. Perencanaan (Planning)

2. Pelaksanaan Tindakan (Action)

3. Observasi dan Evaluasi (Observation dan Evaluation)

4. Refleksi (Reflection)

\section{Teknik Analisis Data}

Menentukan persentase ketuntasan belajar siswa: 
$\%$ Ketuntasan $=\frac{\sum \mathrm{X}}{\mathrm{N}} \times 100 \%$

Menentukan persentase aktivitas mengajar guru:

$\%$ Aktivitas $=\frac{\mathrm{X}}{\mathrm{N}} \times 100 \%$

\section{Menentukan persentase aktivitas belajar siswa:}

$\%$ Aktivitas $=\frac{\mathrm{X}}{\mathrm{N}} \times 100 \%$

(Riduwan, 2005: 25)

\section{Indikator Kinerja}

Data dalam penelitian ini terdiri dari dua jenis yaitu data kualitatif dan kuantitatif, sehingga keberhasilan penelitian ini dilihat dari dua segi yaitu dari segi proses dan dari segi hasil (nilai siswa). Penelitian ini dikatakan berhasil apabila $80 \%$ siswa telah mencapai standar ketuntasan hasil belajar dengan nilai batas ketuntasan belajar minimal 70 sesuai dengan standar KKM (Kriteria Ketuntasan Minimal) yang ditetapkan oleh sekolah. Sedangkan bila dilihat dari segi proses, penelitian ini dikatakan berhasil apabila minimal $80 \%$ pelaksanaan tindakan sesuai dengan skenario pembelajaran yang dapat diketahui melalui pengamatan aktivitas guru dan aktivitas siswa dalam kegiatan pembelajaran.

\section{HASIL DAN PEMBAHASAN}

\section{Hasil dan Pembahasan}

Pembahasan hasil penelitian ini diajukan untuk menemukan jawaban atas permasalahan yang diangkat dalam penelitian. Permasalahannya yaitu apakah kemampuan siswa dalam menulis siswa dapat ditingkatkan melalui penerapan model pembelajaran kooperatif tipe STAD kelas 10 SMK Negeri 1 Tongkuno Kebupaten Muna?

Pada kegiatan pembelajaran siklus I nilai rata-rata menulis puisi bebas belum mencapai nilai yang menjadi target dalam penelitian ini. Ketuntasan hasil belajar siswa pada kemampuan menulis puisi bebas pada siklus I mencapai persentase sebesar $62,5 \%$ atau termasuk dalam kategori kurang. Sedangkan pada siklus II ketuntasan hasil belajar siswa pada kemampuan menulis puisi bebas mencapai $87,5 \%$. Hal ini menunjukkan peningkatan persentase ketuntasan hasil belajar siswa dari siklus I ke siklus II sebesar $25 \%$. Lebih rinci peningkatan kemampuan menulis puisi bebas setelah mendapat pembelajaran melalui penerapan model pembelajaran kooperatif tipe STAD dapat dilihat pada tabel berikut.

Tabel 3 Hasil Tes Kemampuan menulis puisi bebas Pratindakan, Siklus I, dan Siklus II

\begin{tabular}{cccccc}
\hline \multicolumn{3}{c}{ Persentase } & \multicolumn{2}{c}{ Persentase Peningkatan } \\
\hline PT & SI & SII & PT-SI & SI-SII & $\begin{array}{l}\text { PT- } \\
\text { SII }\end{array}$ \\
\hline 60 & 62,5 & 87,5 & 2,5 & 25 & 27,5 \\
\hline
\end{tabular}

Gambar 1. Grafik Persentase Ketuntasan Hasil Belajar Siswa

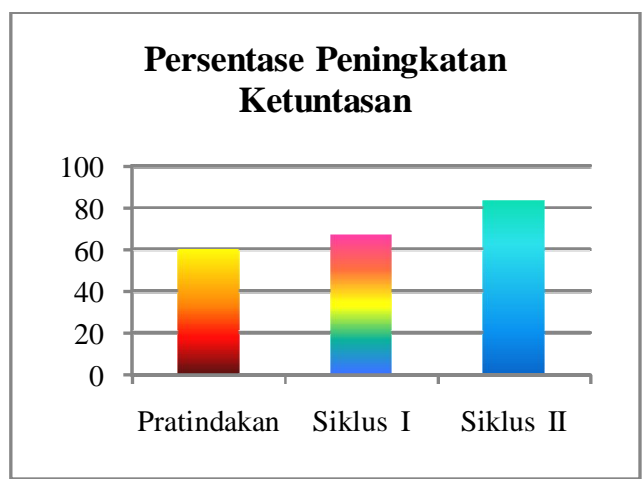


Tabel 3. menunjukkan bahwa persentase ketuntasan hasil belajar siswa pratindakan baru mencapai $60 \%$ dan masih berada pada kategori kurang karena masih berada di bawah standar KKM yang menjadi indikator penelitian. Persentase ketuntasan hasil belajar siswa siklus I secara klasikal mencapai $62,5 \%$ dan berada pada kategori kurang. Nilai tersebut masi belum memenuhi target yang ditetapkan yaitu minimal $80 \%$ siswa memperoleh nilai minmal 70. Pada siklus I siswa mengalami peningkatan sebesar 2,5\% dari nilai pratindakan. Meskipun demikian, masih ada siswa yang memperoleh nilai di bawah nilai ratarata target dan berada pada kategori kurang. Keadaan tersebut disebabkan masih ada siswa yang kurang memperhatikan penjelasan dari guru, berbicara dengan temannya, dan kesulitan mendengarkan pada saat menyimak karena terkadang ada siswa yang agak gaduh, sehingga menyebabkan siswa kurang memahami ataupun lupa pada bagian-bagian tertentu dari isi cerita. Pada siklus II diharapkan KKM yang ditetapkan sebagai indikator penelitian dapat tercapai.

Pada siklus II, Persentase ketuntasan hasil belajar siswa mencapai $87,5 \%$ yang berarti ada peningkatan dari siklus I sebesar $25 \%$ dan berada pada kategori baik. Sedangkan yang masuk kategori kurang masih ada 2 siswa. Pada tabel tersebut juga disajikan peningkatan kemampuan menulis puisi bebas dari pratindakan ke siklus II. Peningkatan tersebut sebesar $27,5 \%$.

Peningkatan nilai siswa dalam pembelajaran menulis puisi bebas disebabkan oleh adanya perbaikanperbaikan yang dilakukan oleh adanya pengetahuan awal dari siswa. Dengan adanya peningkatan persentase ketuntasan hasil belajar siswa tiap siklus membuktikan bahwa pembelajaran menulis puisi bebas melalui penerapan model pembelajaran kooperatif tipe STAD dapat memotivasi siswa dan akhirnya berpengaruh terhadap penguasaan menulis puisi bebas.

Berdasarkan hasil nontes siklus I diketahui bahwa dalam proses pembelajaran menulis puisi bebas melalui penerapan model pembelajaran kooperatif tipe STAD masih ditemukan siswa yang berperilaku negatif seperti mengganggu atau berbicara dengan teman. Perilaku negatif yang dilakukan siswa tersebut disebabkan oleh beberapa faktor diantaranya siswa kurang mengetahui pentingnya kegiatan menyimak dan hal ini berdampak pada kurangnya minat dan motivasi siswa dalam mengikuti kegiatan pembelajarn. Untuk mengatasinya guru berusaha memotivasi siswa dengan menanamkan pada siswa bahwa menyimak merupakan keterampilan yang sangat penting dan mendasar yang dapat berpengaruh terhadap pemahaman mata pelajaran lain.

Berdasaarkan analisis data dapat dijelaskan bahwa perilaku siswa dalam belajar menunjukkan perubahan yang mengarah pada perubahan perilaku positif. Siswa bersemangat dalam belajar dan mereka belajar dengan suasana senang. Selain itu, berdasarkan hasil jurnal siswa pada siklus II diketahui bahwa siswa merasa senang dan tertarik terhadap pembelajaran pembelajaran melalui penerapan model pembelajaran kooperatif tipe STAD karena lebih mudah memahami materi pelajaran yang disimak. Hal ini menambah minat siswa dalam mengikuti kegiatan pembelajaran. Meskipun masih terdapat siswa yang 
berperilaku negatif dalam mengikuti kegiatan menyimak cerita pendek anak, tetapi pada dasarnya mereka senang terhadap kegiatan menulis puisi bebas.

Mereka menganggap menulis puisi sebagai hal yang menarik untuk disimak namun, masih terdapat siswa yang mengungkapkan bahwa siswa merasa kesulitan dalam memahami puisi bebas terutama jika ada temannya yang bersikap gaduh. Untuk mengatasi kesulitan tersebut, siswa diminta mencatat hal-hal penting dan pada siklus berikutnya dilakukan perbaikanperbaikan dalam proses pembelajaran. Tindakan perbaikan tersebut meliputi guru lebih memotivasi siswa dengan menekankan pentingnya keterampilan menyimak dan guru memberi penjelasan bahwa dalam menyimak yang dicatat adalah hal yang penting saja. Selain itu, guru menekankan pada pemberian materi terutama yang masih kurang dipahami oleh siswa dengan memberikan penjelasan dan memperbanyak contoh.

Perbaikan yang dilakukan terhadap pembelajaran menulis puisi bebas melalui penerapan model pembelajaran kooperatif tipe STAD pada siklus II mempengaruhi hasil nilai dan perilaku siswa. Namun terdapat faktor lain yang juga memberi pengaruh terhadap hasil nilai dan perilaku siswa tersebut yaitu intelegensi, kesiapan dan motivasi siswa untuk belajar, pengetahuan awal yang dimiliki siswa tentang menulis puisi bebas, kondisi kelas yang kondusif. Penerapan model pembelajaran kooperatif tipe STAD merupakan hal yang berbeda dari biasanya. Hal ini menyebabkan siswa merasa tertarik dan menemukan sesuatu yang berbeda dari pembelajaran sebelumnya.
Keaktifan siswa sebelum dan setelah dilakukan pembelajaran menulis puisi bebas melalui penerapan model pembelajaran kooperatif tipe STAD pada saat dilaksanakan pembelajaran dapat uraikan sebagai berikut.

Perilaku siswa sebelum dilaksanakan kegiatan pembelajaran menulis puisi bebas melalui penerapan model pembelajaran kooperatif tipe STAD atau pratindakan bahwa, tampak beberapa siswa yang tidak memperhatikan dan mengajak berbicara temannya pada saat guru menjelaskan kegiatan yang akan dilaksanakan yaitu menulis puisi bebas. Pada saat guru menjelaskan materi pelajaran, sebagian siswa mendengarkan penjelasan dari guru, tetapi masih ada siswa yang tidak mendengarkan penjelasan yang disampaikan oleh guru. Siswa tersebut ada yang mengajak temannya berbicara, ada siswa yang menulis, dan ada beberapa yang melakukan kegiatan yang lain. Siswa-siswa tersebut kurang memperhatikan penjelasan dari guru tentang menulis puisi. Siswa-siswa tersebut tampak berusaha menanyakan jawaban dari teman yang lain.

Perilaku siswa setelah dilaksanakan kegiatan pembelajaran menulis puisi bebas penerapan model pembelajaran kooperatif tipe STAD siklus I terlihat sebagian siswa tampak siap dengan kegiatan yang akan dilaksanakan pada hari itu. Meskipun demikian, masih ada siswa yang tampak belum siap dan berbicara dengan temannya pada saat guru menjelaskan kegiatan yang akan dilaksanakan yaitu menulis puisi bebas. Respons siswa terhadap materi pembelajaran lebih baik dari pembelajaran pada pratindakan karena mereka menganggap materi yang akan dipelajari lebih menarik. 
Pada saat guru memberikan materi menulis puisi bebas, sebagian siswa mendengarkan penjelasan dari guru, tetapi masih ada siswa yang sesekali mengajak temannya berbicara, ada siswa yang menulis, dan ada beberapa yang melakukan kegiatan yang lain. Sebagian besar siswa antusias menyimak penjelasan materi pelajaran melalui penerapan model pembelajaran kooperatif tipe STAD. Namun, masih ada siswa yang tampak kurang bersemangat dan mengganggu temannya.

Pada saat siswa mengerjakan tes hasil belajar mengenai menulis puisi bebas yang telah mereka simak, sebagian besar siswa serius mengerjakan soal tersebut, tetapi masih ada siswa yang kesulitan mengerjakan soal karena tidak mendengarkan penjelasan guru tentang materi pelajaran, ada pula yang kesulitan mendengarkan karena pada saat pembelajaran ada beberapa siswa yang ribut.

Perilaku siswa pada pembelajaran menulis puisi bebas melalui penerapan model pembelajaran kooperatif tipe STADsiklus II, terlihat sebagian siswa tampak siap dengan kegiatan yang akan dilaksanakan pada hari itu. Secara umum siswa telah siap mengikuti pembelajaran menulis puisi bebas penerapan model pembelajaran kooperatif tipe STAD. Hal tersebut dapat terlihat dari siswa yang sudah menyiapkan alat tulis dan semangat ketika guru memasuki kelas. Pada saat guru memberikan materi menulis puisi bebas, tampak sebagian besar siswa mendengarkan penjelasan dari guru dengan seksama. Siswa tampak tertarik dan antusias menyimak materi pelajaran. Siswa menyimak dengan sungguh-sungguh, mencatat hal-hal yang penting, dan sesekali mereka tersenyum mendengarkan penjelasan guru. Pada saat siswa mengerjakan tes hasil belajar mengenai menulis puisi bebas yang telah mereka simak, siswa tampak serius mengerjakan soal tersebut.

Berdasarkan uraian tersebut menunjukkan dan membuktikan bahwa penerapan model pembelajaran kooperatif tipe STAD dapat meningkatkan motivasi dalam belajar dan kemampuan siswa serta adanya perubahan perilaku siswa kelas $10 \mathrm{SMK}$ Negeri 1 Tongkuno ke arah positif setelah dilaksanakan pembelajaran menulis puisi bebas melalui penerapan model pembelajaran kooperatif tipe STAD.

\section{KESIMPULAN DAN SARAN}

\section{Kesimpulan}

Dari hasi penelitian yang telah dilaksanakan dapat diambil simpulan sebagai berikut.

1. setelah diadakan penelitian dengan penerapan model pembelajaran kooperatif tipe STAD mengalami peningkatan. Peningkatan kemampuan menulis puisi bebas tersebut diketahui dari hasil pratindakan (observasi awal), siklus I, dan siklus II. Persentase ketuntasan hasil belajar siswa pratindakan sebesar $60 \%$, sedangkan persentase ketuntasan hasil belajar siswa pada siklus I mencapai $62,5 \%$ termasuk dalam kategori kurang. Peningkatan persentase ketuntasan hasil belajar siswa sebesar $2,5 \%$ dari persentase ketuntasan siswa pada hasil pratindakan. Peningkatan dari siklus 
I ke siklus II sebesar 25\%. Pada siklus II, Persentase ketuntasan hasil belajar siswa adalah $87,5 \%$ sehingga persentase ketuntasan hasil belajar siswa mencapai KKM yang ditetapkan sebagai indicator penelitian. Sementara itu, peningkatan dari hasil tes pratindakan ke siklus II yaitu $27,5 \%$.

2. Peningkatan hasil tes juga diikuti oleh perubahan perilaku siswa kelas 10 SMK Negeri 1 Tongkuno ke arah yang lebih positif setelah dilaksanakan pembelajaran menulis puisi bebas melalui penerapan model pembelajaran kooperatif tipe STAD. Hal tersebut dapat diketahui dari hasil nontes yang meliputi hasil observasi, dan dokumentasi foto. Pada pembelajaran siklus I masih banyak siswa yang cenderung pasif, bermalas-malasan, dan kurang memperhatikan penjelasan yang diberikan oleh guru. Namun, pada pembelajaran siklus II perilaku siswa lebih aktif, senang, dan serius terhadap materi ataupun tugas yang diberikan oleh guru. Selain itu, mereka terlihat senang, tertarik, dan antusias dengan pembelajaran yang dilaksanakan, sehingga siswa dapat memahami materi dan tugas yang diberikan oleh guru dapat diselesaikan dengan baik.

\section{Saran}

Penelitian ini dapat digunakan sebagai alternatif pembelajaran khususnya Mata Pelajaran Bahasa Indonesia dan Mata Pelajaran lain yang dapat menggunakan kegiatan menyimak serta mengatasi kesulitan yang dialami siswa. Setelah penelitian dilaksanakan, peneliti memberikan saran sebagai berikut.
1. Guru hendaknya memberikan variasi-variasi dalam kegiatan menulis di antaranya dengan penerapan model pembelajaran kooperatif tipe STAD untuk menambah minat siswa dalam belajar.

2. Apabila guru menerapkan model pembelajaran kooperatif tipe STAD hendaknya mempersiapkan secara baik, mempertimbangkan kelas yang akan digunakan, dan jam pelajaran yang akan digunakan untuk pembelajaran. Hal ini harus diperhatikan supaya pembelajaran melalui kegiatan menulis dapat efektif dan tidak mengganggu proses pembelajaran mata pelajaran yang lain.

3. Bagi pembaca disarankan untuk lebih intensif dalam menyimak karena sangat bermanfaat bagi kehidupan.

\section{DAFTAR PUSTAKA}

Asma. 2006. Belajar dan Pembelajaran. Jakarta: Rineka Cipta.

Ibrahim. 2000. Pembelajaran Kooperatif. Surabaya: UNS University Press.

Ismail. 2002. Model-model Pembelajaran. Jakarta: Direktorat Sekolah Lanjutan Tingkat Pertama. Jakarta Dirjen Dikdasmen Depdiknas.

Nurgiyantoro B. 2005. Sastra Anak (Pengantar Pemahaman Dunia Anak). Yogyakarta: Gadjah Mada University Press 
Riduwan. 2005. Dasar-dasar Statistik. Bandung: Alphabeta.

Sugiyanto, 2010. Model-model Pembelajaran Inovatif. Surakarta: Yuma pustaka.

Sugondo. 1999. Berbahasa dengan Baik dan Benar. Jakarta. Rosdakarya Putra.

Tarigan, Henry G. 1994 Menyimak Sebagai Suatu Keterampilan Berbahasa. Bandung: Angkasa

Trianto, 2010. Mendesain Model Pembelajaran InovatifProgresif. Kharisma Putra Utama. Surabaya 